\title{
Article \\ Effect of Silane Functionalization on Properties of Poly(Lactic Acid)/Palygorskite Nanocomposites
}

\author{
Anton Kasprzhitskii ${ }^{1,2}{ }^{-}$, Georgy Lazorenko ${ }^{1,2, * \mathbb{C}}$, Alexander Kruglikov ${ }^{1}$, Irina Kuchkina ${ }^{3}$ and Vadim Gorodov ${ }^{4}$ \\ 1 Department of Physics, Rostov State Transport University, Narodnogo Opolcheniya Sq., \\ 344038 Rostov-on-Don, Russia; akasprzhitsky@yandex.ru (A.K.); aleksan.kruglikov@yandex.ru (A.K.) \\ 2 Mineralica Limited Liability Company, Skolkovo Innovation Center, 42 Bolshoy Boulevard, \\ 121205 Moscow, Russia \\ 3 Enikolopov Institute of Synthetic Polymer Materials, Russian Academy of Sciences, 70 Profsoyuznaya Street, \\ 117393 Moscow, Russia; kuchkinaio@ispm.ru \\ 4 Nesmeyanov Institute of Organoelement Compounds, Russian Academy of Sciences, 28 Vavilova Street, \\ 119991 Moscow, Russia; gorodovvv@ispm.ru \\ * Correspondence: glazorenko@yandex.ru
}

check for

updates

Citation: Kasprzhitskii, A.;

Lazorenko, G.; Kruglikov, A.;

Kuchkina, I.; Gorodov, V. Effect of

Silane Functionalization on Properties of Poly(Lactic Acid)/Palygorskite

Nanocomposites. Inorganics 2021, 9, 3.

https://doi.org/10.3390/

inorganics 9010003

Received: 30 November 2020

Accepted: 24 December 2020

Published: 2 January 2021

Publisher's Note: MDPI stays neutral with regard to jurisdictional clai$\mathrm{ms}$ in published maps and institutional affiliations.

Copyright: (C) 2021 by the authors. Licensee MDPI, Basel, Switzerland. This article is an open access article distributed under the terms and conditions of the Creative Commons Attribution (CC BY) license (https:// creativecommons.org/licenses/by/ $4.0 /)$.

\begin{abstract}
Poly(lactic acid) (PLA)/ palygorskite (Paly) nanocomposites were prepared using the melt compounding technique. Paly modified by 3-aminopropyltriethoxysilane (APTES) and vinyltrime thoxysilane (VTMS) was used as nanofiller for PLA with concentrations in the $1-7 \mathrm{wt} \%$ range. It has been found that the functionalization allows a covalent bond between the hydroxyl groups of the Paly and the PLA matrix, evidenced by the improvement in mechanical properties. Paly modification with VTMS has better properties compared with Pale modification with APTES. This indicates a better adhesion between the Paly-VTMS and PLA matrix, and a good dispersion of the nanofiller in the polymer matrix.
\end{abstract}

Keywords: palygorskite; coupling agent; poly(lactic acid); 3-aminopropyltriethoxysilane; vinyltrime thoxysilane

\section{Introduction}

Poly(lactic acid) or polylactide (PLA) is a biodegradable polymer synthesized from renewable resources such as corn, rice, potatoes, or sugarcane [1,2]. It is of greater interest because of its manufacturability during heat treatment, high melting point, plasticity [2,3], the possibility of recycling [4,5], biocompatibility, good biodegradation rate [6-8], as well as relatively low cost [9]. Moreover, upon degradation, PLA breaks down into non-toxic components [10]. This opens up prospects for the introduction of PLA in a wide range of production areas, primarily in the food and agricultural sectors of the economy, as a material for packaging, as well as in the pharmaceutical and medical industries [11]. However, the use of PLA has limitations associated with its high brittleness, low elongation at break, low impact strength, and poor crystallizability. Its low mechanical, barrier properties, and low thermal stability in comparison with major industrial polymers limit the extensive use of PLA in its native form [12-19]. The addition of reinforcing components into the PLA polymer matrix allows expanding the possibilities of its application [20,21]. In this case, the morphology of the filler and its compatibility with the polymer matrix play a key role in improving the physical and mechanical properties of the nanocomposite [22]. In most studies on the improvement of PLA properties, the researchers used layered aluminosilicates as a filler, in particular montmorillonite and its organomodified forms [23-26]. Still, the question of the effect of morphology on the physical and mechanical properties of PLA is insufficiently investigated [11]. In this respect, it is interesting to study palygorskite (also known as attapulgite) with a fiber morphology (with diameter up to $25 \mathrm{~nm}$ and length up to $1000 \mathrm{~nm}$ ) and a porous structure (the size of nano-channels is $0.64 \times 0.37 \mathrm{~nm}$ ), having 
the following chemical formula: $(\mathrm{Si}, \mathrm{Al})_{8} \mathrm{O}_{20}(\mathrm{Mg}, \mathrm{Al}, \mathrm{Fe})_{5}(\mathrm{OH})_{2}\left(\mathrm{OH}_{2}\right)_{4} 4 \mathrm{H}_{2} \mathrm{O}$, where $\mathrm{H}_{2} \mathrm{O}$ is zeolitic water, $\mathrm{OH}_{2}$ is coordinated water, and $\mathrm{OH}$ is structural water [27]. A large surface area and needle-like morphology of palygorskite (Paly) raise the possibility of obtaining a pronounced reinforcing effect at polymer nanocomposites. Using organomodification for Paly should not only provide dispersion of the mineral in the polymer matrix, but also enhance their interaction. This is manifested in the improvement of the mechanical and thermal properties of the nanocomposite containing Paly [28-32]. One of the strategies for organomodification of clay minerals is the grafting silylation reaction. Silane is used as a coupling agent because of its ability to react with clays by hydrolysis/condensation, and its end groups can also react with polymers. The effect in this case is achieved owing to the formation of covalent bonds [33,34]. In this case, it is interesting to evaluate the effect of Paly modification with various silanes on the properties of PLA/Paly nanocomposites, which has been poorly understood until recently. However, there are examples of successful applications of silanes for other clay minerals [35-37].

The aim of this work is to carry out a comparative analysis of the effect of pre-modified Paly on the morphological, mechanical, and thermal properties of PLA/Paly nanocomposites. 3-aminopropyltriethoxysilane (APTES) and vinyltrimethoxysilane (VTMS) were chosen as Paly modifiers. The nanocomposites were prepared by melt blending. For comparative evaluation, a multiple research was performed using Fourier transform infrared spectroscopy (FTIR), mechanical bending tests, transmission electron microscopy (TEM), thermogravimetric analysis (TGA), and differential scanning calorimetry (DSC).

\section{Material and Methods}

\subsection{Materials}

PLA (4032D) with a number average molecular weight of $200 \mathrm{kDa}$ was obtained from NatureWorks LLC (Minnetonka, MN, USA). Palygorskite (Cimsil G30) was purchased from TOLSA S.A. (Madrid, Spain). The silanes (3-aminopropyltriethoxysilane and vinyltrimethoxysilane) were purchased from MAS Albion Ltd. (Moscow, Russia). The structures of chemical compounds are given in Table 1.

Table 1. Structure and chemical characteristics of poly(lactic acid) and silane molecules.

\begin{tabular}{|c|c|c|c|}
\hline Label & Chemical Name & Structural Formula & Molecular Weight (g/mol) \\
\hline PLA & Polylactide Ingeo 4032D & & $123,000.00$ \\
\hline APTES & 3-Aminopropyltriethoxysilane & & 221.37 \\
\hline VTMS & Vinyltrimethoxysilane & & 148.23 \\
\hline
\end{tabular}

\subsection{Modification of Palygorskite}

The Paly functionalization procedure is shown in Figure 1. For homogenization, Paly $(1 \mathrm{~g})$ was mixed with ethyl alcohol $(20 \mathrm{~g})$. The resulting mixture was subsequently subjected to $30 \mathrm{~min}$ of ultrasonic treatment (magnetostrictive emitter with the frequency of $22 \mathrm{kHz}$, 
amplitude of $50 \mu \mathrm{m}$, and output power of $500 \mathrm{~W}$ ) and $30 \mathrm{~min}$ of mixing on a magnetic stirrer (1500 rpm at room temperature) (Figure 1a). For modification, APTES or VTMS ( $250 \mathrm{mg}$ ) was added to the mixture. Then, the mixture was brought to $\mathrm{pH} 4.5-5.5$ by adding a solution of acetic acid $(1.25 \mathrm{~mL})$ in deionized water $(30 \mathrm{~mL})$. The resulting mixture was stirred for $4 \mathrm{~h}$ on a magnetic stirrer $\left(1500 \mathrm{rpm}, 65^{\circ} \mathrm{C}\right)$ (Figure 1b). Finally, the sample was centrifuged at $9000 \mathrm{rpm}$ to obtain a solid substance, after which it was dried at room temperature.
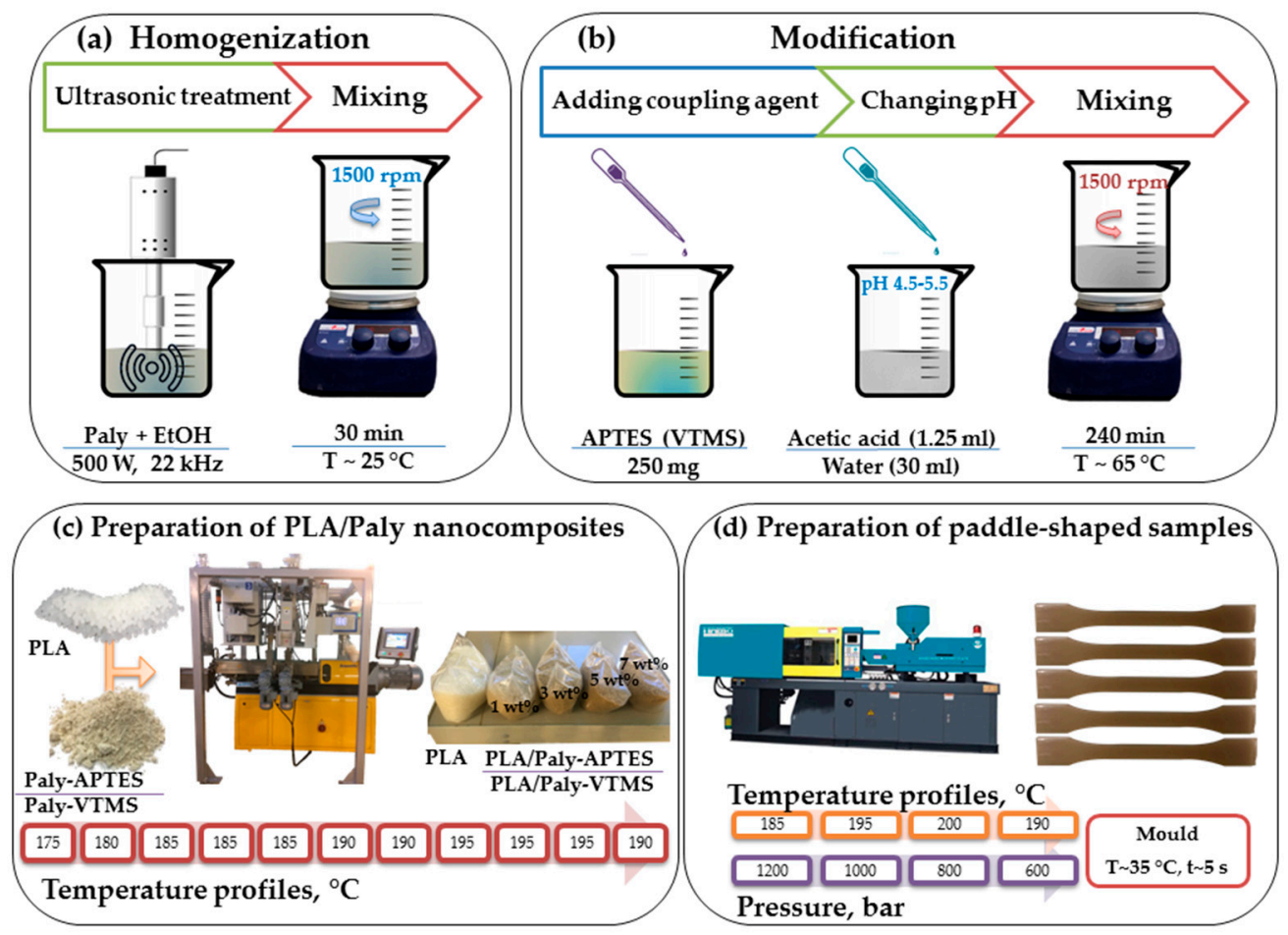

Figure 1. Schematic representation of the processes for modification of Paly $(\mathbf{a}, \mathbf{b})$ and preparation of poly(lactic acid) (PLA)/palygorskite (Paly) nanocomposites (c,d). APTES, 3-aminopropyltriethoxysilane; VTMS, vinyltrimethoxysilane.

\subsection{Preparation of Poly(Lactic Acid)/Palygorskite Nanocomposites}

PLA/Paly nanocomposites with 1, 3, 5, and $7 \mathrm{wt} \%$ filler content (Paly-APTES and Paly-VTES) were prepared using the melt extrusion technique using LTE 26-48 co-rotating twin-screw extruder, with a screw speed of $80 \mathrm{rpm}$. Before processing, the PLA and the filler were dried for $12 \mathrm{~h}$ at $80{ }^{\circ} \mathrm{C}$. This blending process was conducted with temperature profiles of the extruder barrels; the ten zones of the hopper were 175, 180, 185, 185, 185, 190, $190,195,195,195$, and head $190^{\circ} \mathrm{C}$. The extrudate was then passed through a chilled water bath and pelletized. The scheme for obtaining PLA/Paly-APTES or PLA/Paly-VTMS is depicted in Figure 1c. The PLA, PLA/Paly-APTES, and PLA/Paly-VTMS paddle-shaped samples $(150 \times 20 \times 4 \mathrm{~mm})$ were prepared in injection molding machine (Haibo HBT700L) at $185,195,200$, and head $190{ }^{\circ} \mathrm{C}$ cylinder temperature, and $35^{\circ} \mathrm{C}$ mould temperature at $5 \mathrm{~s}$ holding time under the pressure range of 1200-600 bar (Figure 1d).

\subsection{Characterization Methods}

Fourier transform infrared (ALPHA-E; Bruker, Billerica, MA, USA) spectroscopy was used to analyze the chemical structures of the nanocomposites. The spectrum ranged from 500 to $4000 \mathrm{~cm}^{-1}$, the resolution was $4 \mathrm{~cm}^{-1}$, and the number of scans was 32 . Flexural modulus was measured according to ASTM D790-17 standard using ZwickiLine Materials Testing machine $5 \mathrm{kN}$ at a constant crosshead speed of $2 \mathrm{~mm} / \mathrm{min}$. By transmission electron 
microscopy (Tecnai Spirit G2; Philips, Amsterdam, The Netherlands), the dispersion of Paly-APTES or Paly-VTMS in PLA/Paly nanocomposite was observed. A synchronous thermal analyzer (STA 449 F3; NETSCH, Selb, Germany) combining thermo gravimetric analysis with differential scanning calorimetry was used. The effect of Paly-APTES or Paly-VTMS on the thermal stability of the nanocomposite was studied. In synchronous mode (TGA and DSC), we used the sample weighing about 6-9 $\mathrm{mg}$, and the temperature was raised from $40{ }^{\circ} \mathrm{C}$ to $500{ }^{\circ} \mathrm{C}$ with a heating rate of $10^{\circ} \mathrm{C} / \mathrm{min}$. Argon (air) was used as the purge and protection gas, and the flow rate of argon (air) was $30 \mathrm{~mL} / \mathrm{min}$. Corundum crucibles with a hole in the lid were used for measurements. In DSC mode, the test volume was about $6-9 \mathrm{mg}$, and the temperature was raised from $25^{\circ} \mathrm{C}$ to $300{ }^{\circ} \mathrm{C}$ with a heating rate of $10{ }^{\circ} \mathrm{C} / \mathrm{min}$. It was cooled from $300^{\circ} \mathrm{C}$ to $25^{\circ} \mathrm{C}$ at a cooling rate of $5^{\circ} \mathrm{C} / \mathrm{min}$. Sealed aluminum crucibles were used for measurements.

\section{Results and Discussion}

\subsection{FTIR Analysis}

The FTIR spectra of pristine Paly and silane-functionalized Paly are displayed in Figure 2. FTIR spectrum of Paly demonstrates tetrahedral (Si-O-Si, 950-1250 cm ${ }^{-1}$ ) [38,39] and octahedral (Al-Al-OH, $913 \mathrm{~cm}^{-1}$; Al-Fe-OH, $865 \mathrm{~cm}^{-1}$; and $\mathrm{Mg}-\mathrm{Mg}-\mathrm{OH}, 647 \mathrm{~cm}^{-1}$ [40]) vibrations with bands connected with hydroxyl groups and water molecules in the range $3200-3400,3562 \mathrm{~cm}^{-1}$ [41], and $1668 \mathrm{~cm}^{-1}$ [42], respectively.

Surface modification of the Paly using APTES is revealed in a decrease in the intensity of Si-O vibrations due to the response of APTES and Paly [38,39] (Figure 2a). The vibrational frequencies of silane molecules interacting with fibrous silicates are in the range of $1200-2000 \mathrm{~cm}^{-1}$. The band at $1630 \mathrm{~cm}^{-1}$ is associated with the stretching vibration $\mathrm{C}=\mathrm{C}$, and the band at $1720 \mathrm{~cm}^{-1}$ is associated with the stretching vibration $\mathrm{C}=\mathrm{O}[42,43]$. In addition, new peaks at 1566, 1496, and $690 \mathrm{~cm}^{-1}$ (Figure $2 \mathrm{~b}$ ), which correspond to bending vibrations of $-\mathrm{NH}_{2},-\mathrm{CH}_{2}$, and deformation of $-\mathrm{CH}$ out of plane, once again confirm this conclusion $[44,45]$. All these observations are consistent with the APTES grafting onto the Paly surface [46]. In Paly modification with silane (Figure 2c), there occurs a new peak at $2930 \mathrm{~cm}^{-1}$, and one more small hump at $2850 \mathrm{~cm}^{-1}$, associated with $\mathrm{C}-\mathrm{H}$ asymmetric and symmetric stretching of the $-\mathrm{CH}_{2}$ groups, which confirms the presence of silane on the mineral surface [47].

Surface modification of the Paly surface using VTMS is characterized by new Si-O-Si bands appearing in the FTIR spectrum at 1120, 1080, 1031, and $790 \mathrm{~cm}^{-1}$ [48-51] (Figure 2a). Moreover, stripes with asymmetric stretch $-\mathrm{CH}_{2}$ at $3062 \mathrm{~cm}^{-1}, \mathrm{C}=\mathrm{C}$ stretch at $1600 \mathrm{~cm}^{-1}$, and $-\mathrm{CH}$ in-plane band at $1274 \mathrm{~cm}^{-1}$ (Figure $2 \mathrm{~b}, \mathrm{c}$ ) [52]. Thus, the presence of silane bands in all spectra of functionalized clays confirms that the $\mathrm{OH}$ group on the inner/outer surface and edge of clays can chemically react with alkoxysilane Si-OR groups.

FTIR spectra of PLA, PLA/Paly-APTES, and PLA/Paly-VTMS are shown in Figure 3. For PLA, there are stretching frequencies for $\mathrm{C}=\mathrm{O}$, asymmetric, and symmetric vibrations of $-\mathrm{CH}_{3}$ group at 1746, 2997, and $2943 \mathrm{~cm}^{-1}$, respectively. At $1180 \mathrm{~cm}^{-1}$, one can observe a band associated with the $\mathrm{O}-\mathrm{C}-\mathrm{O}$ groups, as well as three peaks at 1128, 1081, and $1042 \mathrm{~cm}^{-1}$ belonging to the $\mathrm{C}-\mathrm{C}-\mathrm{O}$ group. In addition, bending frequencies for $-\mathrm{CH}_{3}$ are determined at 1452, 1380, and $1359 \mathrm{~cm}^{-1}[53,54]$. In Figure 3a, the excess of the intensity of the maximum in the region of $1650 \mathrm{~cm}^{-1}$ is observed, related to the hygroscopic water of Paly oscillation, for PLA/Paly-APTES with $5 \mathrm{wt} \%$ filler content over a sample containing $7 \mathrm{wt} \%$ filler; this can be attributed to the heterogeneity of filler distribution in the PLA matrix witnessed in TEM images (Section 3.3). 

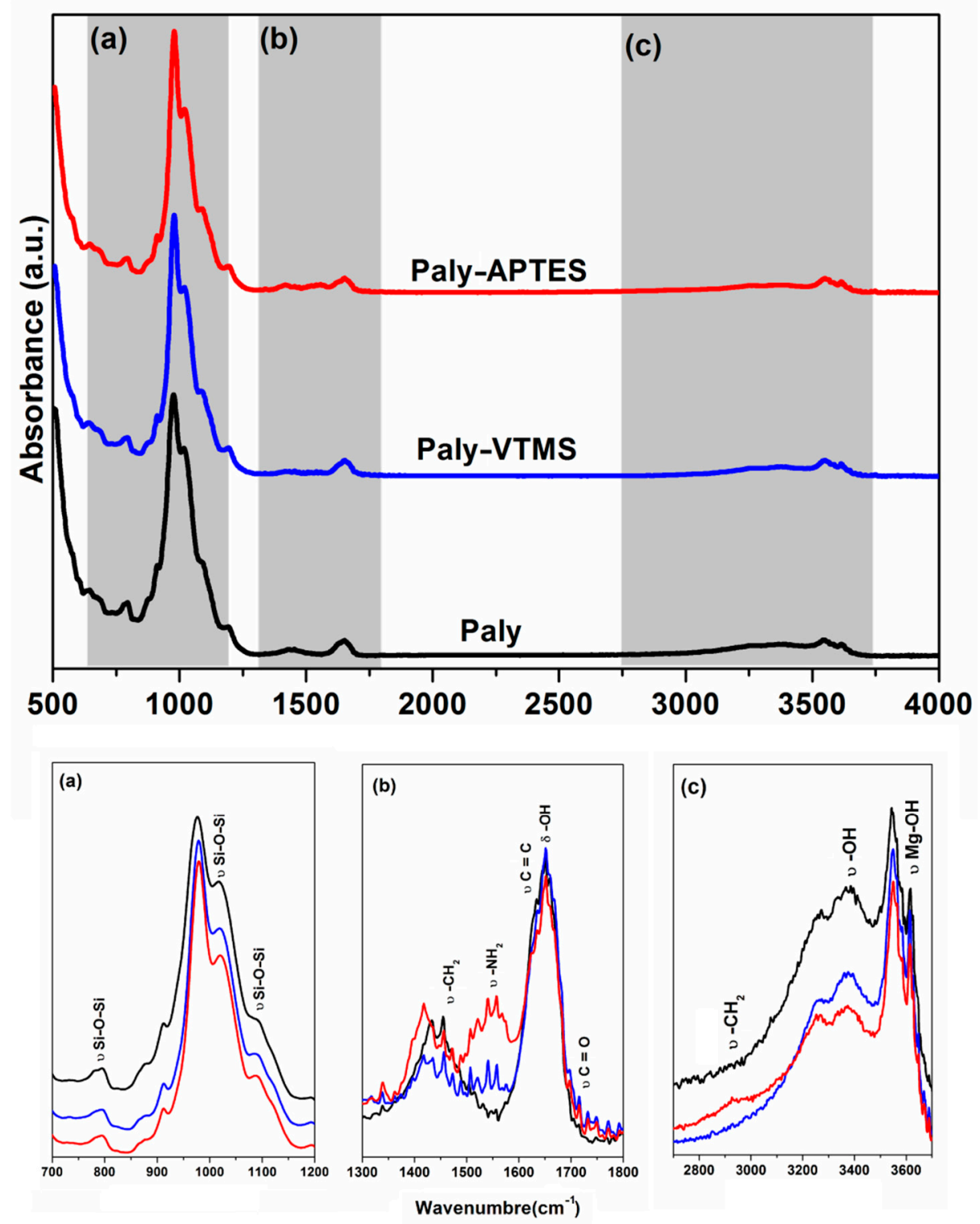

Figure 2. Fourier transform infrared (FTIR) spectra of Paly, Paly-APTES, and Paly-VTES for wavenumber $\left(\mathrm{cm}^{-1}\right)$ ranges: $^{-}$ (a) 700-1200; (b) 1300-1800; and (c) 2700-3700.

This finding shows that there is less accessibility of surface hydroxyl groups because of the modification of the Paly surface with a silane. The carbonyl group that appears at $1745 \mathrm{~cm}^{-1}$ for pure PLA shifts slightly towards the higher wavenumber $\left(1746 \mathrm{~cm}^{-1}\right)$ in the PLA/Paly-APTES and PLA/Paly-VTMS nanocomposites in the case of $7 \mathrm{wt} \%$ content of Paly-APTES (Paly-VTMS), indicating a certain degree of chemical interaction between Paly-APTES (Paly-VTMS) and PLA matrix. In this case, the largest number of surfaceactive groups of the Paly-APTES (Paly-VTMS) filler interacting with the PLA matrix may be retained. 

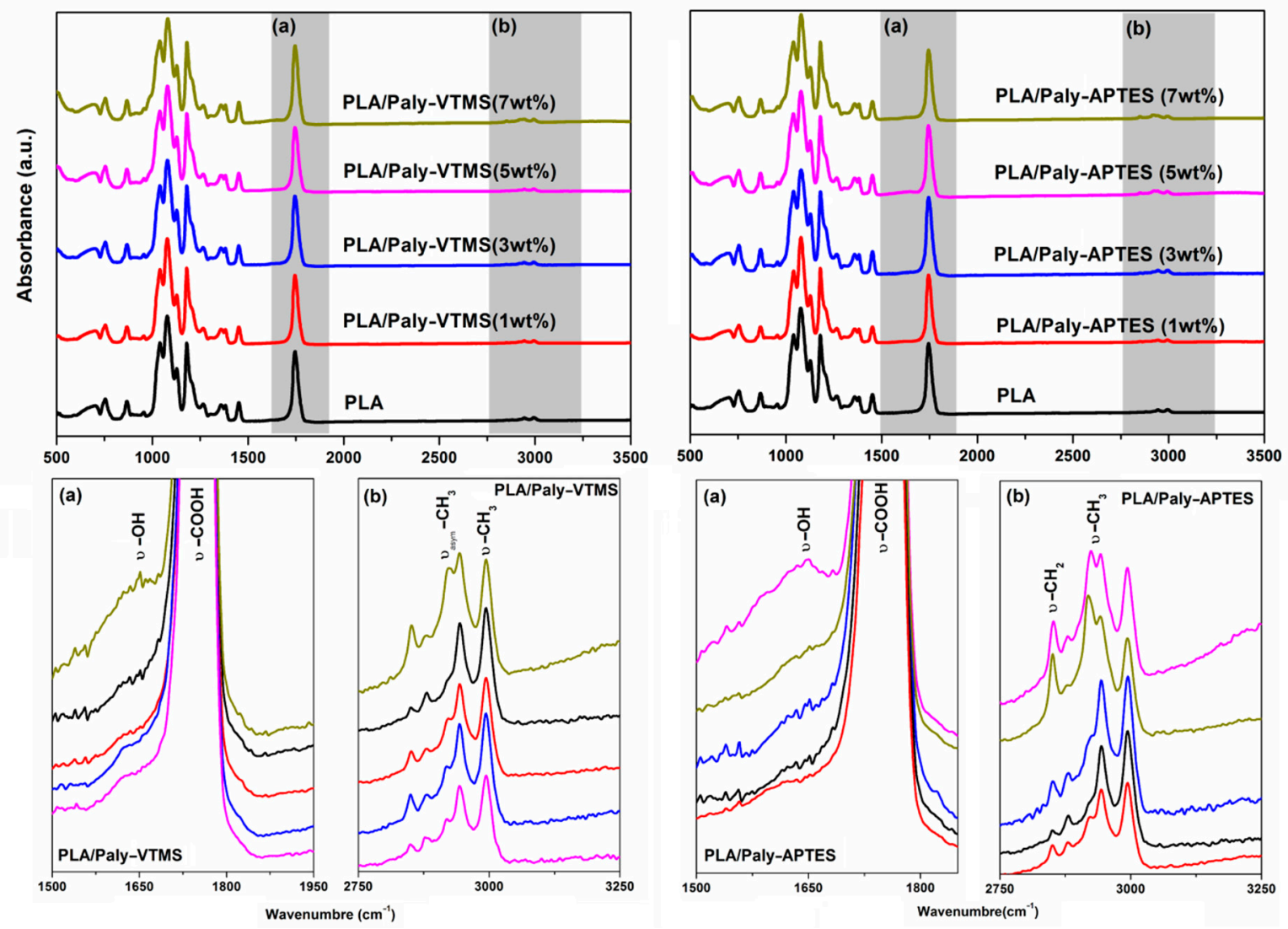

Figure 3. FTIR spectra of PLA, PLA/Paly-VTMS, and PLA/Paly-APTES for wavenumber ( $\mathrm{cm}^{-1}$ ) ranges: (a) 1500-1950 and (b) 2750-3250.

\subsection{Mechanical Properties}

The flexural modulus of PLA, PLA/Paly-APTES, and PLA/Paly-VTMS nanocomposites is shown in Figure 4. The increase in flexural strength modulus with increasing silylated Paly concentration to $7 \mathrm{wt} \%$ indicates a positive effect of silanization on nanofiller dispersion in the PLA polymer matrix. The overall flexural strength of PLA/Paly-VTMS composites is higher than that of PLA/Paly-APTES. This happens owing to better interfacial adhesion between the matrix and filler, which improves stress transfer and leads to higher flexural strength values. The presence of agglomerates with an increasing concentration of Paly-APTES is also the reason for underestimated values of the flexural modulus of PLA/Paly-APTES composites. A simultaneous increase in the flexure modulus for PLA/Paly-APTES and PLA/Paly-VTMS nanocomposites with the addition of $1 \mathrm{wt} \%$ silylated Paly compared with pure PLA from 3.3 GPa to 3.392 and $3.394 \mathrm{GPa}$, respectively, was witnessed. This indicates that Paly intrinsic stiffness has a positive effect on the overall stiffness of the PLA/Paly nanocomposites, which increases the flexural modulus of nanocomposites. Improving the flexural modulus for PLA and its nanocomposites is important for sustainable packaging applications [55] as it is a measure of the stiffness of a material. The positive effect of functionalization with silanes APTES and VTMS of clay minerals such as montmorillonite, halloysite, and sepiolite on the mechanical properties of thermoplastic polymers was also scrutinized by Raji et al. [39]. 


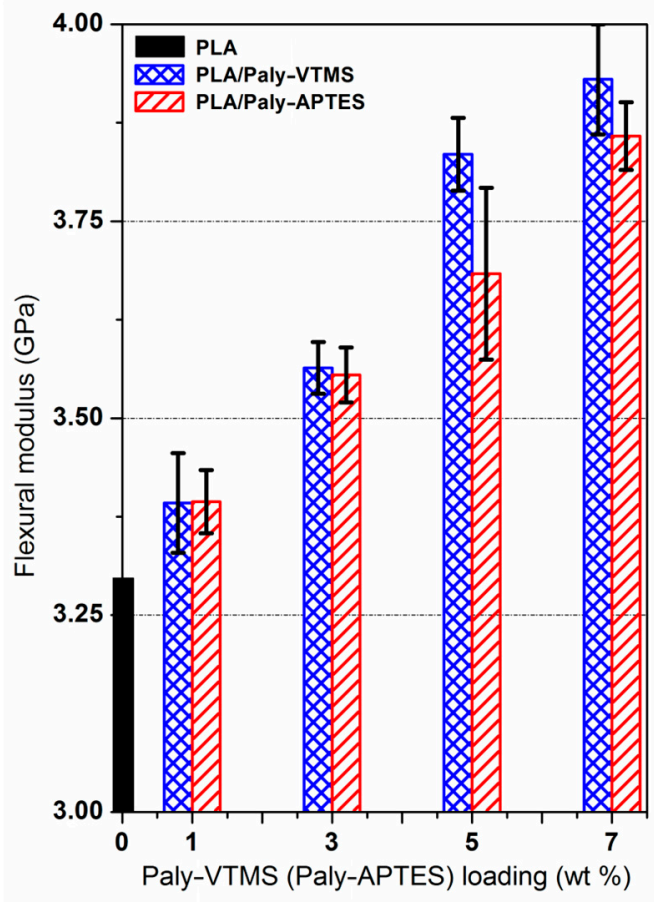

Figure 4. The flexural modulus of PLA/grafted Paly nanocomposites.

\subsection{Morphology Analysis}

Paly-VTMS particles are dispersed in the PLA polymer matrix, which can be clearly seen in Figure 5a. Despite the concentration of $7 \mathrm{wt} \%$ Paly-VTMS in the polymer matrix, no signs of particle agglomeration are detected, which indicates a clear interaction between Paly-VTMS and the PLA matrix. In contrast, for Paly-APTES particles in the PLA matrix for the case of $7 \mathrm{wt} \%$ concentration, areas of particle agglomeration are observed (Figure $5 b$ ). This indicates a reduced interaction between the modified APTES Paly and polymer matrix.
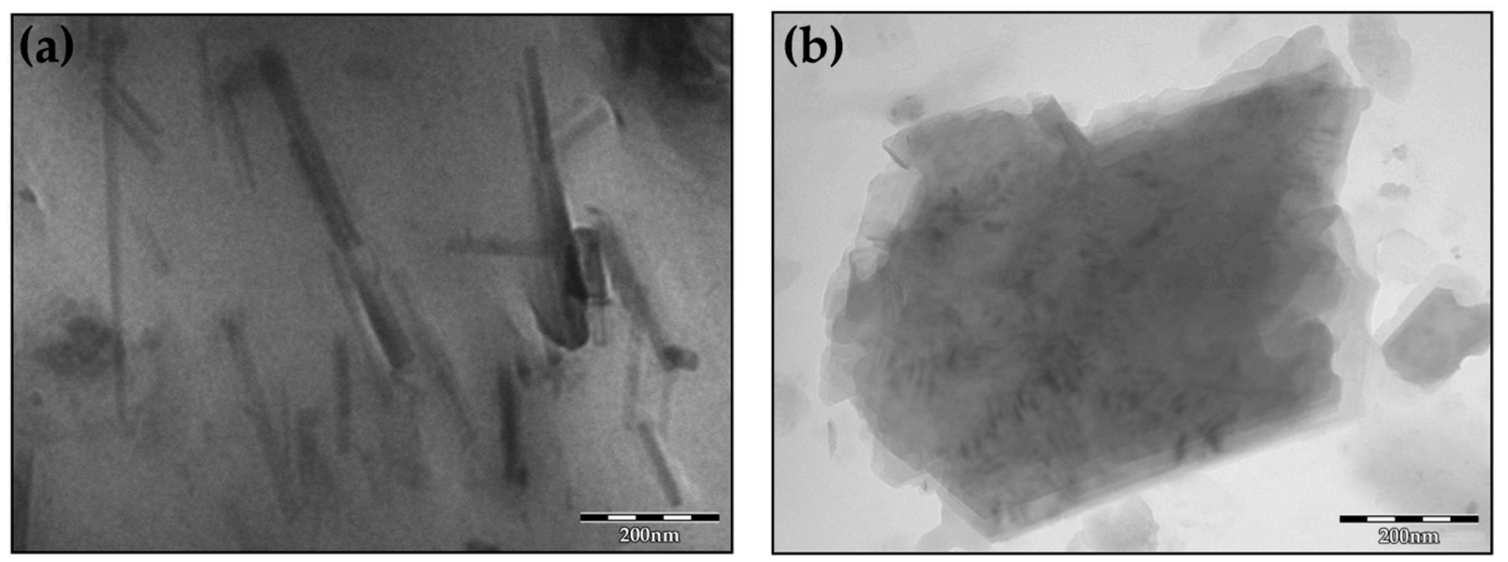

Figure 5. Transmission electron microscopy (TEM) micrographs of (a) PLA/Paly-VTMS (7 wt $\%$ ) and (b) PLA/Paly-APTES (7 wt\%) nanocomposites.

\subsection{Thermogravimetric Analysis}

Figure 6 displays the TGA curves of PLA, PLA/Paly-VTMS, and PLA/Paly-APTES samples. At temperatures up to $300{ }^{\circ} \mathrm{C}$, the mass of PLA/Paly-VTMS (Figure 6a,c) and PLA/Paly-APTES (Figure 6b,d) samples is stable in both argon atmosphere and air. At temperatures above $300-305^{\circ} \mathrm{C}$ in argon atmosphere and in air, there is pyrolytic decom- 
position of all samples, with an almost complete loss of weight by $380^{\circ} \mathrm{C}$. Closer to $500{ }^{\circ} \mathrm{C}$, the residual mass of PLA/Paly-VTMS and PLA/Paly-APTES samples increases. This is due to the increase in the content of the Paly-APTES and Paly-VTMS filler remaining after heating (Table 2).
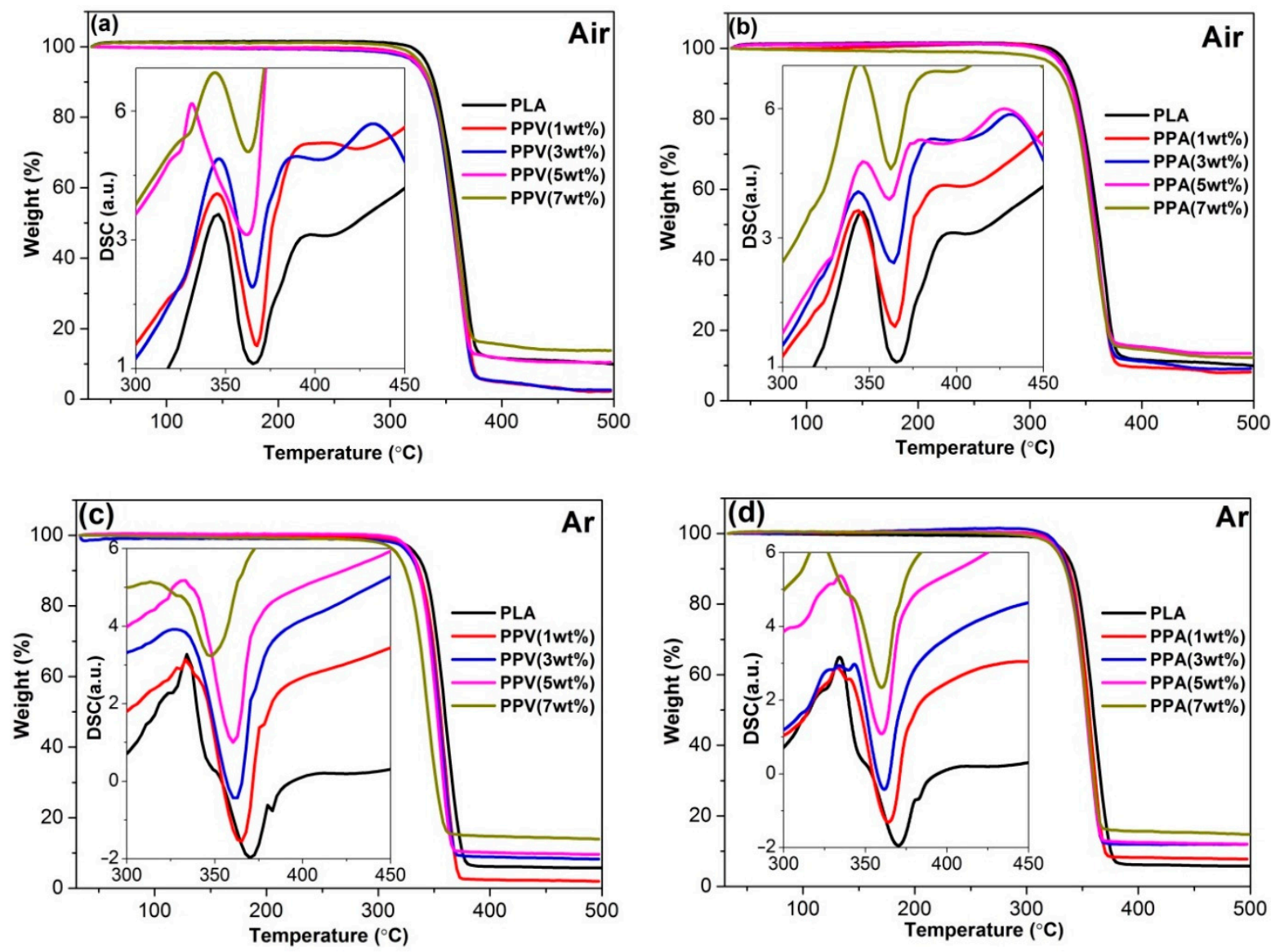

Figure 6. Thermogravimetric analysis (TGA) and differential scanning calorimeter (DSC) curves of PLA nanocomposites with different proportions of PPV (Paly-VTMS) and PPA (Paly-APTES) addition in air (a,b) and in argon atmosphere (c,d).

Table 2. Thermal parameters obtained from thermogravimetric analysis (TGA) and differential scanning calorimeter (DSC) analysis (in argon). PPV, Paly-VTMS.

\begin{tabular}{|c|c|c|c|c|}
\hline Sample & $\begin{array}{c}\text { Glass Transition } \\
\text { Temperature, } \mathrm{T}_{\mathrm{g}}\left({ }^{\circ} \mathrm{C}\right)\end{array}$ & $\begin{array}{c}\text { Melting Temperature, } \\
\mathrm{T}_{\mathrm{m}}\left({ }^{\circ} \mathrm{C}\right)\end{array}$ & $\begin{array}{l}\text { Crystallinity Index, } \\
\qquad X_{c}(\%)\end{array}$ & Weight Loss (\%) \\
\hline PLA & 59 & 170 & 0.9 & 94.2 \\
\hline PPV (1 wt\%) & 59 & 170 & 17.6 & 98.0 \\
\hline PPV (3wt\%) & 60 & 170 & 34.0 & 91.7 \\
\hline PPV (5 wt $\%)$ & 60 & 170 & 41.2 & 90.4 \\
\hline PPV (7 wt $\%)$ & 61 & 163 & 11.4 & 86.1 \\
\hline PPA (1 wt $\%)$ & 59 & 170 & 15.6 & 92.2 \\
\hline PPA (3 wt $\%)$ & 57 & 168 & 29.1 & 88.1 \\
\hline PPA (5 wt $\%)$ & 58 & 168 & 42.4 & 88.0 \\
\hline PPA $(7 w t \%)$ & 61 & 164 & 23.5 & 85.2 \\
\hline
\end{tabular}

\subsection{Differential Scanning Calorimetry}

Figure 6 represents the DSC curves of PLA, PLA/Paly-VTMS, and PLA/Paly-APTES samples. With an increase in the content of silanized Paly from 1 to $5 \mathrm{wt} \%$, an augmentation 
in the crystallinity index $\left(X_{c}\right)$ is detected, which indicates that the clay filler can act as a nucleation agent to induce the PLA crystallization [56,57]. Adding $7 w t \%$ silanized Paly diminishes this effect (Table 2). An increase in crystallinity results in a higher glass transition temperature $\left(\mathrm{T}_{\mathrm{g}}\right)$. The addition of silanized Paly to PLA did not significantly affect the melting temperature $\left(\mathrm{T}_{\mathrm{m}}\right)$, except for samples with $7 \mathrm{wt} \%$ filler content, indicating a better packaging and organization caused by the clay filler [58]. Similar behavior was also observed in the work of Lai et al. for PLA nanocomposites filled with organic-modified montmorillonite clay [56].

\section{Conclusions}

Nanocomposites based on PLA and modified palygorskite were prepared by melt blending. Palygorskite was modified with two organosilanes (APTES and VTMS), which promoted the formation of covalent bonds between the polymer and the clay through reactive extrusion, allowing strong interactions between the clay and the PLA matrix. Spectral studies were performed to characterize the successful grafting of silanes onto palygorskite. It has been found that the functionalization method allows a covalent bond between the hydroxyl groups of the clay minerals and the polymer matrix, as evidenced by the improvement in mechanical properties. Thus, for the flexural modulus, PLA increases from $3300 \mathrm{MPa}$ to $3930 \mathrm{MPa}$ at $7 \mathrm{wt} \%$ for Paly-VTMS. The obtained results prove that silylation of palygorskite is an important method for increasing the interfacial adhesion between palygorskite and the PLA matrix.

Author Contributions: Conceptualization, A.K. (Anton Kasprzhitskii) and G.L.; methodology, A.K. (Anton Kasprzhitskii); investigation, A.K. (Anton Kasprzhitskii), G.L., A.K. (Alexander Kruglikov), I.K., and V.G.; resources, G.L.; writing-original draft preparation, A.K. (Anton Kasprzhitskii); writing-review and editing, G.L.; visualization, A.K. (Anton Kasprzhitskii); project administration, A.K. (Anton Kasprzhitskii). All authors have read and agreed to the published version of the manuscript.

Funding: The work was performed according to the state assignment of the Federal Agency for Railway Transport of the Russian Federation (protocol ROSZHELDOR of 15.04.2020 No.VCh-23). The company had no role in the design of the study; in the collection, analyses, or interpretation of data; in the writing of the manuscript, or in the decision to publish the results.

Institutional Review Board Statement: Not applicable.

Informed Consent Statement: Not applicable.

Data Availability Statement: The data presented in this study are available on request from the corresponding author.

Acknowledgments: Investigation of TGA and DSC characteristics was made using the equipment of the Collaborative Access Center "Center for Polymer Research" of ISPM RAS.

Conflicts of Interest: The authors declare no conflict of interest.

\section{References}

1. Pandey, J.K.; Reddy, K.R.; Kumar, A.P.; Singh, R.P. An overview on the degradability of polymer nanocomposites. Polym. Degrad. Stab. 2005, 88, 234-250. [CrossRef]

2. Lim, L.-T.; Auras, R.; Rubino, M. Processing technologies for poly(lactic acid). Prog. Polym. Sci. 2008, 33, 820-852. [CrossRef]

3. Auras, R.; Harte, B.; Selke, S. An Overview of Polylactides as Packaging Materials. Macromol. Biosci. 2004, 4, 835-864. [CrossRef] [PubMed]

4. Piemonte, V.; Sabatini, S.; Gironi, F. Chemical recycling of PLA: A great opportunity towards the sustainable development? J. Polym. Environ. 2013, 21, 640-647. [CrossRef]

5. Plichta, A.; Lisowska, P.; Kundys, A.; Zychewicz, A.; Debowski, M.; Florjanczyk, Z. Chemical recycling of poly(lactic acid) via controlled degradation with protic (macro) molecules. Polym. Degrad. Stab. 2014, 208, 288-296. [CrossRef]

6. Dorgan, J.R.; Lehermeier, H.J.; Palade, L.I.; Cicero, J. Poly lactides: Properties and prospects of an environmentally benign plastic from renewable resources. Macromol. Symp. 2001, 175, 55-66. [CrossRef]

7. Pantani, R.; Sorrentino, A. Influence of crystallinity on the biodegradation rate of injection-moulded poly(lactic acid) samples in controlled composting conditions. Polym. Degrad. Stab. 2013, 98, 1089-1096. [CrossRef] 
8. Gorrasi, G.; Pantani, R. Effect of PLA grades and morphologies on hydrolytic degradation at composting temperature: Assessment of structural modification and kinetic parameters. Polym. Degrad. Stab. 2013, 98, 1006-1014. [CrossRef]

9. Garlotta, D. A Literature Review of Poly(Lactic Acid). J. Polym. Environ. 2011, 9, 63-84. [CrossRef]

10. Nel, A.; Xia, T.; Mädler, L.; Li, N. Toxic potential of materials. Science 2007, 311, 622-627. [CrossRef]

11. Raquez, J.-M.; Habibi, Y.; Murariu, M.; Dubois, P. Polylactide (PLA)-based nanocomposites. Prog. Polym. Sci. 2013, 38, 1504-1542. [CrossRef]

12. Rasal, R.M.; Janorkar, A.V.; Hirt, D.E. Poly(lactic acid) modifications. Prog. Polym. Sci. 2010, 35, 338-356. [CrossRef]

13. Anderson, K.S.; Schreck, K.M.; Hillmyer, M.A. Toughening polylactide. Polym. Rev. 2008, 48, 85-108. [CrossRef]

14. Liu, H.; Zhang, J. Research progress in toughening modification of poly(lactic acide). J. Polym. Sci. Part B Polym. Phys. 2011, 49, 1051-1083. [CrossRef]

15. Fortunati, E.; Armentano, I.; Iannoni, A.; Barbale, M.; Zaccheo, S.; Scavone, M.; Visai, L.; Kenny, J.M. New multifunctional poly(lactide acid) composites: Mechanical, antibacterial, and degradation properties. J. Appl. Polym. Sci. 2012, 124, 87-98. [CrossRef]

16. Rosli, N.A.; Ahmad, I.; Anuar, F.H.; Abdullah, I. Mechanical and thermal properties of natural rubber-modified poly(lactic acid) compatibilized with telechelic liquid natural rubber. Polym. Test. 2016, 54, 196-202. [CrossRef]

17. Rasal, R.M.; Hirt, D.E. Toughness decrease of PLA-PHBHHx blend films upon surface-confined photopolymerization. J. Biomed. Mater. Res. Part A 2008, 88A, 1079-1086. [CrossRef] [PubMed]

18. Hiljanen-Vainio, M.; Varpomaa, P.; Seppala, J.; Tormala, P. Modification of poly(l-lactides) by blending: Mechanical and hydrolytic behavior. Macromol. Chem. Phys. 1997, 197, 1503-1523. [CrossRef]

19. Grijpma, D.W.; Nijenhuis, A.J.; Van Wijk, P.G.T.; Pennings, A.J. High impact strength as-polymerized PLLA. Polym. Bull. 1992, 29, 571-578. [CrossRef]

20. Kruglikov, A.; Vasilchenko, A.; Kasprzhitskii, A.; Lazorenko, G. Atomic-level understanding of interface interactions in a halloysite nanotubes-PLA nanocomposite. RSC Adv. 2019, 9, 39505-39514. [CrossRef]

21. Bordes, P.; Pollet, E.; Avérous, L. Nano-biocomposites: Biodegradable polyester/nanoclay systems. Prog. Polym. Sci. 2009, 34, 125-155. [CrossRef]

22. Ray, S.S.; Okamoto, M. Polymer/layered silicate nanocomposites: A review from preparation to processing. Prog. Polym. Sci. 2003, 28, 1539-1641. [CrossRef]

23. Paul, M.A.; Alexandre, M.; Degèe, P.; Henrist, C.; Rulmont, A.; Dubois, P. New Nanocomposite Materials Based on Plasticized Poly(L-Lactide) and Organo-Modified Montmorillonites: Thermal and Morphological Study. Polymer 2003, 44, 443. [CrossRef]

24. Lazorenko, G.; Kasprzhitskii, A.; Yavna, V. Synthesis and structural characterization of betaine- and imidazoline-based organoclays. Chem. Phys. Lett. 2018, 692, 264-270. [CrossRef]

25. Alexandre, M.; Dubois, P. Polymer-layered silicate nanocomposites: Preparation, properties and uses of a new class of materials. Mater. Sci. Eng. R Rep. 2000, 28, 1-63. [CrossRef]

26. Lazorenko, G.; Kasprzhitskii, A.; Yavna, V. Comparative study of the hydrophobicity of organo-montmorillonite modified with cationic, amphoteric and nonionic surfactants. Minerals 2020, 10, 732. [CrossRef]

27. Suárez, M.; García-Romero, E. Advances in the crystal chemistry of sepiolite and palygorskite. Elsevier Developm. Clay Sci. 2011, 3 , 33-65. [CrossRef]

28. Yin, H.; Chen, H.; Chen, D. Viscoelastic behavior of poly(acrylonitrile)/attapulgite nanocomposite solution. Colloids Surf. A Physicochem. Eng. Asp. 2010, 367, 52. [CrossRef]

29. Sun, L.; Yang, Z.; Li, X. Effects of the treatment of attapulgite and filler contents on tensile properties of PTFE and attapulgite reinforced fabric composites. Compos. A 2009, 40, 1785. [CrossRef]

30. Shen, L.; Lin, Y.; Du, Q.; Zhong, W. Studies on structure-property relationship of polyamide-6/attapulgite nanocomposites. Compos. Sci. Technol. 2006, 66, 2242. [CrossRef]

31. Peng, L.; Zhou, L.; Li, Y.; Pan, F.; Zhang, S. Synthesis and properties of waterborne polyurethane/attapulgite nanocomposites. Compos. Sci. Technol. 2011, 71, 1280. [CrossRef]

32. Hu, F.; Li, T.; Zhong, F.; Wen, S.; Zheng, G.; Gong, C.; Qin, C.; Liu, H. Preparation and properties of chitosan/acidified attapulgite composite proton exchange membranes for fuel cell applications. J. Appl. Polym. Sci. 2020, 137, 49079. [CrossRef]

33. Bujdák, J.; Danko, M.; Chorvát, D.; Czímerová, A.; Sýkora, J.; Lang, K. Selective modification of layered silicate nanoparticle edges with fluorophores. Appl. Clay Sci. 2012, 65-66, 152-157. [CrossRef]

34. Piscitelli, F.; Posocco, P.; Toth, R.; Fermeglia, M.; Pricl, S.; Mensitieri, G.; Lavorgna, M. Sodium montmorillonite silylation: Unexpected effect of the aminosilane chain length. J. Colloid Interface Sci. 2010, 351, 108-115. [CrossRef] [PubMed]

35. Silva, A.A.; Dahmouche, K.; Soares, B.G. Nanostructure and dynamic mechanical properties of silane-functionalized montmorillonite/epoxy nanocomposites. Appl. Clay Sci. 2011, 54, 151-158. [CrossRef]

36. Ianchis, R.; Corobea, M.C.; Donescu, D. Advanced functionalization of organoclay nanoparticles by silylation and their polystyrene nanocomposites obtained by miniemulsion polymerization. J. Nanopart. Res. 2012, 14, 1233. [CrossRef]

37. Maisanaba, S.; Ortuño, N.; Jordá-Beneyto, M.; Aucejo, S.; Jos, A. Development, characterization and cytotoxicity of novel silane-modified clay minerals and nanocomposites intended for food packaging. Appl. Clay Sci. 2017, 138, 40-47. [CrossRef]

38. Fan, Q.H.; Shao, D.D.; Hu, J.; Wu, W.S.; Wang, X.K. Comparison of $\mathrm{Ni}^{2+}$ sorption to bare and ACT-graft attapulgites: Effect of pH, temperature and foreign ions. Surf. Sci. 2008, 602, 778-785. [CrossRef] 
39. Raji, M.; Mekhzoum, M.E.M.; Rodrigue, D.; Qaiss, A.E.K.; Bouhfid, R. Effect of silane functionalization on properties of polypropylene/clay nanocomposites. Compos. B Eng. 2018, 146, 106-115. [CrossRef]

40. Mishra, A.K.; Allauddin, S.; Narayan, R.; Aminabhavi, T.M.; Raju, K.V.S.N. Characterization of surface-modified montmoril-lonite nanocomposites. Ceram. Int. 2012, 38, 929-934. [CrossRef]

41. Cai, Y.; Xue, J.; Polya, D.A. A Fourier transform infrared spectroscopic study of Mg-rich, Mg-poor and acid leached palygorskites. Spectrochim. Acta Part A Mol. Biomol. Spectrosc. 2007, 66, 282-288. [CrossRef] [PubMed]

42. Helmy, A.K.; de Bussetti, S.G.; Ferreiro, E.A. The surface energy of palygorskite. Powder Technol. 2007, 171, 126-131. [CrossRef]

43. Posthumus, W.; Magusin, P.C.M.M.; Brokken-Zijp, J.C.M.; Tinnemans, A.H.A.; van der Linde, R. Surface modification of oxidic nanoparticles using 3-methacryloxypropyltrimethoxysilane. J. Colloid Interface Sci. 2004, 269, 109-116. [CrossRef] [PubMed]

44. Yan, W.; Yuan, P.; Chen, M.; Wang, L.; Liu, D. Infrared spectroscopic evidence of a direct addition reaction between palygorskite and pyromellitic dianhydride. Appl. Surf. Sci. 2013, 265, 585-590. [CrossRef]

45. De Faria, E.H.; Ciuffi, K.J.; Nassar, E.J.; Vicente, M.; Trujillano, R.; Calefi, P.S. Novel reactive amino-compound: Tris(hydroxymethyl) aminomethane covalently grafted on kaolinite. Appl. Clay Sci. 2010, 48, 516-521. [CrossRef]

46. Xue, A.; Zhou, S.; Zhao, Y.; Lu, X.; Han, P. Effective $\mathrm{NH}_{2}$-grafting on attapulgite surfaces for adsorption of reactive dyes. J. Hazard. Mater. 2011, 194, 7-14. [CrossRef]

47. Laaziz, S.A.; Raji, M.; Hilali, E.; Essabir, H.; Rodrigue, D.; Bouhfid, R.; el kacem Qaiss, A. Bio-composites based on polylactic acid and argan nut shell: Production and properties. Int. J Biol. Macromol. 2017, 104, 30-42. [CrossRef]

48. Marini, M.; Pourabbas, B.; Pilati, F.; Fabbri, P. Functionally modified core-shell silica nanoparyicles by one-pot synthesis. Colloids Surf. A 2008, 317, 473-481. [CrossRef]

49. Wang, L.H.; Sheng, J. Controlled/ «Living» radical polymerization. Halogen atom transfer radical polymerization promoted by a $\mathrm{Cu}(\mathrm{I}) / \mathrm{Cu}(\mathrm{II})$ redox process. J. Macromol. Sci. Part A Pure Appl. Chem. 2003, 40, 1135-1146. [CrossRef]

50. Olejniczak, Z.; Łęczka, M.; Cholewa-Kowalska, K.; Wojtach, K.; Rokita, M.; Mozgawa, W. 29Si MAS NMR and FTIR study of inorganic-organic hybrid gels. J. Mol. Struct. 2005, 744, 465-471. [CrossRef]

51. Wu, Z.; Ahn, I.-S.; Lee, C.-H.; Kim, J.-H.; Shul, Y.G.; Lee, K. Enhancing the organic dye adsorption on porous xerogels. Colloids Surf. A 2004, 240, 157-164. [CrossRef]

52. Kuznetsova, A.; Wovchko, E.A.; Yates, J.T. FTIR study of the adsorption and thermal behavior of vinyltriethoxysilane chemisorbed on $\gamma-\mathrm{Al}_{2} \mathrm{O}_{3}$. Langmuir 1997, 13, 5322-5328. [CrossRef]

53. Chieng, B.W.; Ibrahim, N.A.; Wan Yunus, W.M.Z.; Hussein, M.Z. Effects of graphene nanopletelets on poly(lactic acid)/poly(ethylene glycol) polymer nanocomposites. Adv. Mater. Res. 2014, 1024, 136-139. [CrossRef]

54. Fortunati, E.; Luzi, F.; Puglia, D.; Dominici, F.; Santulli, C.; Kenny, J.M.; Torre, L. Investigation of thermo-mechanical, chemical and degradative properties of PLA-limonene films reinforced with cellulose nanocrystals extracted from Phormium tenax leaves. Eur. Polym. J. 2014, 56, 77-91. [CrossRef]

55. Armentano, I.; Bitinis, N.; Fortunati, E.; Mattioli, S.; Rescignano, N.; Verdejo, R.; Lopez-Manchado, M.A.; Kenny, J.M. Multifunctional nanostructured PLA materials for packaging and tissue engineering. Prog. Polym. Sci. 2013, 38, 1720-1747. [CrossRef]

56. Lai, S.-M.; Wu, S.-H.; Lin, G.-G.; Don, T.-M. Unusual mechanical properties of melt-blended poly(lactic acid) (PLA)/clay nanocomposites. Eur. Polym. J. 2014, 52, 193-206. [CrossRef]

57. Fukushima, K.; Tabuani, D.; Camino, G. Poly(lactic acid)/clay nanocomposites: Effect of nature and content of clay on morphology, thermal and thermo-mechanical properties. Mater. Sci. Eng. C 2012, 32, 1790-1795. [CrossRef]

58. Gomez-Gamez, A.B.; Yebra-Rodriguez, A.; Peñas-Sanjuan, A.; Soriano-Cuadrado, B.; Jimenez-Millan, J. Influence of clay percentage on the technical properties of montmorillonite/polylactic acid nanocomposites. Appl. Clay Sci. 2020, $198,105818$. [CrossRef] 